\title{
Career Adaptability of Young Adults: Psychological Aspect of Professional Socialization
}

\author{
Julita Navaitienè
}

Lithuanian University of Educational Sciences, Faculty of Education, Department of Psychology, Studentų St. 39, LT-08106 Vilnius, Lithuania, julita.navaitiene@leu.lt

\begin{abstract}
Relating the process of professional socialisation to professional adaptability and age, the hypothesis is raised that professional adaptability of young adults is lower than that of mature adults. The survey of 44 part-time students of different age from Lithuanian University of Educational Sciences applying the Career Adapt-Abilities Scale (CAAS) (Savickas, Porfeli, 2012) revealed that professional adaptability of young adults is statistically significantly lower than that of mature adults.
\end{abstract}

Keywords: professional socialisation, proactive socialisation, professional adaptability.

Scientific problem. Professional socialisation is a process of formation of knowledge, skills and attitudes of an individual, who seeks to become a member of a professional community (Clouder, 2003; Keltikangas \& Martinsuo, 2009; Melrose et al., 2012). Three aspects may be distinguished in various definitions of professional socialisation: the first one, which is related to success of internalisation of professional values characteristic of members of professional group; the second aspect, which emphasises importance of accepting norms of professional behaviour and the third one, which reveals the necessity for professional identity formation. The process of professional socialisation may be analysed from the sociological and psychological perspective.

Professional socialisation is a process, when knowledge, abilities, interests, values and roles, which ensure individual's professionalism and his / her development. Both institutions of vocational education as well as employers are concerned about the efficiency of the process of professional socialisation. 
Institutions of vocational education offer programmes, which facilitate their management of the process of students' professional socialisation and provide opportunities to acquire professional knowledge, abilities and attitudes, which are necessary for successful performance of a professional role. The professional role is revealed through familiarisation of learners with assignments, which will have to be completed during professional activities applying the acquired knowledge and abilities.

Employers draw up integration-adaptation plans to ensure efficient professional socialisation and successful completion of assignments set by a professional role. Seeking to be competent, an employer adapts to expectations of an employer and colleagues related to performance of professional roles.

The researchers have presented several models of professional socialisation processes (Bragg, 1976; Cohen, 1981; Stark et al., 1986; Twale \& Kochan, 1999; Weidman et al., 2001; Schoen, 2007). On the basis of E.Erikson's psychosocial theory of human development and H. Kelman's theory of social influence, Cohen (1981) defined four stages of professional socialisation:

1. The stage of unilateral dependence, when individual's professional socialisation is controlled externally (by another person or a group of people). Professional socialisation occurs adopting knowledge, which is transferred by a representative of professional activities or a group of such people, as well as receiving his / her or their evaluation, incentives or punishments. If an individual relies on a representative or representatives of professional activities, $\mathrm{s} /$ he makes attempts to acquire as much professional knowledge as possible.

2. In the stage of negative / independence individual's professional socialisation occurs repeating the model of professional activities suggested by a representative or representatives of professional activities, practically following the model of behavioural norms and values of his / her or them. In this phase an individual actively develops own professional abilities applying theoretical professional knowledge in professional activities. External control is getting weaker, the activities of a representative or representatives of professional activities are evaluated critically. If an individual is sufficiently self-dependent, his / her professional socialisation is developing successfully.

3. The stage of dependence / mutuality enables an individual to understand that results of his / her professional activities have to be acceptable to society and professionals. Limits of professional activities are learnt and tested, professional attitudes and values are enhanced, the model for professional activities is discovered and it helps to combine requirements of professional activities with personal needs, self-confidence increases. If individual's environment is favourable for enhancement of his/her mastery, the process of professional socialisation is successful. 
4. During the stage of interdependence individual's professional identity, internal professional activity motivation are formed, a professional role is fully internalised but changes in future are possible.

To ensure success of individual's professional socialisation, all the four stages are needed.

Professional socialisation is a dynamic, interactive and life-long process (Shinyashiki et al., 2006). The results of this process is a professional self-image, a concept of professional role, internalised professional attitudes and values, professional identity and personal traits necessary in professional activities. Basova (2012) emphasises the importance of professional socialisation in institutions of professional education. These institutions propose the model for professional's role and students have to adapt to it.

The efficiency of the process of professional socialisation may be analysed from the perspective of professional adaptability making attempts to identify the extent to which an individual efficiently adapts to requirements of profession and labour market requirements in order to become a member of professional community, who successfully performs his / her professional role (Pulakos et al., 2006). Fast changes in labour market, instability and insecurity of contemporary professional career encourage individuals to enhance their professional adaptability.

Super (1990) argues that professional adaptability facilitates setting of individual's learning and professional career goals, which are adapted to the self-image as well as to possibilities and limitations of environment. Savickas (1997) determines professional adaptivity as a preparation to cope with assigned tasks, preparing for and performing a professional role, and unpredicted corrections related to changes in work itself and working conditions. Nurmi (2004) determines professional adaptability as a dynamic process, which facilitates goals of professional career and, if these goals are unachievable or lose attractiveness, this process helps to adapt to new ones and/or to compensate them. Heckhausen et al. (2010) describes various variants of such adaptability. Professionally adaptive individuals give up unachievable goals and search for compromise or set alternative goals. Professionally unadaptive people continue with their vain efforts (Wrosch et al., 2003). Individual's professional adaptability is manifested through explorations of own professional potential, planning actions of professional career and making decisions (Creed et al., 2009). Savickas (2011) defines professional adaptability as management of professional development assignments, coping with work-related changes and adaptation to traumas and emergencies at work.

Savickas (2005), Hall \& Zikic (2010), Blustein (2011), Del Corso, Rehfuss \& Galvin (2011), Del Corso (2013) emphasised the importance of the dimension of curiosity in professional adaptability. A curious person is open to new experience and better knows him self or herself. S/he is more flexible as knows and is able to draw up more varied plans of professional career. Savickas and Porfeli (2011) present another three dimensions of professional adaptability: concern, control and confidence. The dimension of concern 
discloses individual's orientation to future and thinking of own professional carrier in the perspective of time. The dimension of control shows responsibility for own professional career and perception of own personal independence. The dimension of confidence is linked to personal ability to attain own goals and particularly ones, whereof achievement is obstructed. The Career Adapt-Abilities Scale (CAAS) was designed to conduct research on the aforesaid dimensions (Savickas, Porfeli, 2012) and it is widely applied in the research on professional adaptability (Glawin, Berger, 2013), (Tolentino, 2014).

Heslin (2005) presents five possible ways for improvement of professional adaptability and one of them is proactive socialisation. The researcher links this way with information-seeking, feedback seeking, relation-building, negotiating job changes and positive framing and emphasises that an individual has to acknowledge and weaken own psychical defence and to believe in own abilities to change.

Determining links of professional adaptability with employability skills, de Guzman \& Choi (2013) point to the importance of individual's abilities to communicate, collaborate and adapt in the changing working environment. It is necessary to emphasise that these abilities are developed in the process of professional socialisation.

Compared to teenagers, young adults make more pragmatic decisions regarding their learning and professional career, posses more real self-concepts because they have accumulated more extensive life experience and pursue personal values more actively. Fadjukoff et al. (2010) states that contemporary young adults are more curious and flexible compared to mature adults, therefore their professional adaptability should be stronger.

The question is raised whether it is true that the elder the person, the more professionally socialised s / he is. Waugaman \& Lohrer (2000) conducted a survey of the sample of 1106 students searching for correlation of age, gender and professional socialisation. One group of the sample included a group of 20-30 year old students, whereas the other group embraced 31-40 year old respondents. The research results showed that the age of the respondents was statistically significantly $(\mathrm{p}<0.05)$ linked to professional socialisation by a negative correlation. Jankauskienè (2009) conducted research on 1346 nurses and established that age influences professional socialisation. Valutis, Rubin \& Bell (2012) also made a conclusion that age is related to professional socialisation. Seada \& Sleem (2012) investigated the process of socialisation within the sample of 160 students. Having analysed the research data, it was disclosed that groups of different age statistically significantly differed in the extent of their social socialisation.

Relating the process of professional socialisation with professional adaptability, the need to explore the correlation between professional adaptability and age. There emerges a problematic question: if professional socialisation may be linked with age, is professional adaptability of young adults lower than that of mature adults.

The goal of the research: to carry out research in professional adaptivity of young and mature adults. 


\section{The objectives of the research:}

1. to conduct research on professional adaptivity of young adults.

2. to carry out research on professional adaptivity of mature adults.

3. to compare professional adaptivity of young and mature adults.

Hypothesis: professional adaptivity of young adults is lower compared to that of mature ones.

\section{The methodology of research}

The sample of the respondents included $44(\mathrm{~N}=44)$ students of Lithuanian University of Educational Sciences: 23 young adults (the age of the youngest respondent in this group was 21 year old, whereas the eldest was 25 years old, the average age is $M=23.1$ years) and 21 mature adult (the youngest respondent in this group was 35 years old, whereas the oldest one was 41 years old, the average age is $M=37.8$ years).

Having received the oral consent from the respondents, the paper versions of the Career Adapt-Abilities Scale (CAAS) were distributed to them and later returned to the researcher. The survey lasted 10-15 minutes.

The Career Adapt-Abilities Scale (CAAS) (Savickas, Porfeli, 2012) was used to measure professional adaptability. It targets at investigation of four dimensions of professional adaptability. The respondents were provided with 24 statements about strengths (abilities); for example, statement 2 "To perceive that today's choices predetermine my future", statement 18: "To be interested in new opportunities", statement 21: "To learn new skills". The respondents were requested to indicate the extent to which they developed the listed strengths (abilities) using a 5-point Likert scale from "strongest" to "weak" and, thus, to evaluate their strength.

The scale contains 4 sub-scales: concern, control, curiosity and confidence with six statements. The values of the concern sub-scale reveal the ability of the respondents to reflect own professional future and to prepare for possible changes, the values of control sub-scale show the respondents' self-control and self-dependence. The values of curiosity sub-scale are linked with reflection of various professional roles and situations. The confidence sub-scale contributes to identification of the respondents' responsibility and independence while planning professional career.

Porfeli and Savickas (2012) present the Cronbach's alpha of the professional adaptivity scales (0.92) and sub-scales (from 0.74 to 0.85 ). During the research slightly lower value of the Cronbach's alpha scale (0.87) was received, whereas the validity of the sub-scales fluctuated from 0.79 to 0.95 . 


\section{The research results and their discussion}

The research date were analysed employing SPSS program (version 17.0). The mean values $(\mathrm{M})$ of professional adaptivity and standard deviations (SD) were presented. The comparison of the data of two independent research groups was carried out employing non-parameter Mann-Whitney U test as the numbers of the respondents in groups were low.

The mean value of professional adaptivity in the whole sample was $M=15.41$, whereas the standard deviation totalled $\mathrm{SD}=1.69$, in the concern sub-scale the aforesaid values amounted $\mathrm{M}=4.12$ and $\mathrm{SD}=0.81$, in the control sub-scale $\mathrm{M}=3.76$ and $\mathrm{SD}=0.76$ respectively, in the curiosity sub-scale: $\mathrm{M}=3.80$ and $\mathrm{SD}=0.68$ and in the confidence sub-scale $\mathrm{M}=3.73$ and $\mathrm{SD}=0.99$ respectively.

Below the results of the research are presented according to the groups of the respondents (see: Table).

Table. The mean values (M), standard deviations (SD) and statistical significance of differences among groups ( $\mathrm{p}$ ) of young and mature adults' professional adaptability

\begin{tabular}{|l|c|c|c|c|c|c|c|c|}
\hline & \multicolumn{2}{|c|}{ Young adults } & \multicolumn{2}{|c|}{ Mature adults } & Mann-Whi- & Wilcoxon \\
tney U & W & Z & p \\
\cline { 2 - 9 } & $\mathrm{M}$ & $\mathrm{SD}$ & $\mathrm{M}$ & $\mathrm{SD}$ & $\mathbf{2}$ & & \\
\hline $\begin{array}{l}\text { Professional } \\
\text { adaptability }\end{array}$ & 14.297 & 1.523 & 16.633 & 0.779 & 31.500 & 307,000 & -4.935 & 0.001 \\
\hline Concern & 3.906 & 1.024 & 4.355 & 0.413 & 175.000 & 451.500 & -1.551 & 0.121 \\
\hline Control & 3.191 & 0.464 & 4.393 & 0.466 & 10.500 & 286.500 & -5.429 & 0.001 \\
\hline Curiosity & 4.307 & 0.428 & 3.233 & 0.389 & 12.000 & 243.000 & -5.394 & 0.001 \\
\hline Confidence & 2.892 & 0.471 & 4.650 & 0.388 & 0.000 & 276.000 & -5.675 & 0.001 \\
\hline
\end{tabular}

From the data presented in the table, it can be seen that the mean values of professional adaptability differ in groups of adults from different age groups (young adults $\mathrm{M}=$ 14.30 , whereas that of mature adults equalled $M=16.63$ ). The difference between young and mature adults is statistically significant $(\mathrm{p}=0.001)$. The professional adaptability of mature adults $(M=16.63)$ is higher than that of young adults $(M=14.30)$.

Analysing the research data at level of professional adaptability, it was established that the mean values of professional adaptability in the sub-scales fell from $\mathrm{M}=2.89$ to $M=4.31$ in the group of young adults. The highest mean of values were observed in the sub-scale of curiosity $(\mathrm{M}=4.31)$, the lowest ones were revealed in the sub-scale of confidence $(\mathrm{M}=2.89)$. It can be assumed that young adults are interested in and reflect own professional roles and professional future, however, their confidence, sense of responsibility and self-dependent are not strongly expressed. The mean values of professional adaptability in the group of mature adults went down from 4.65 to 3.23. The highest 
mean of values were revealed in the sub-scale of confidence $(M=4.65)$, the lowest ones were observed in the sub-scale of curiosity $(M=3.23)$. It can be concluded that mature adults feel responsibility and self-dependence while reflecting on their professional career, though their interest in their profession is not strongly expressed.

The comparison of the mean values of professional adaptability of young and mature adults in the sub-scale of concern revealed a statistically insignificant difference ( $\mathrm{p}=$ 0.12 ). Both young and mature adults were able to reflect on their professional future in a similar way and to prepare for possible changes in their professional career.

Comparing the mean values of young and mature adults in the sub-scale of control of the professional adaptability, a statistically significant difference was observed ( $\mathrm{p}=$ 0.001). The ability of mature adults to self-control, their responsibility for own professional career and perception of own personal self-dependence $(\mathrm{M}=4.39)$ are better expressed compared to young adults $(\mathrm{M}=3.12)$.

Comparing the mean values of young and mature adults in the sub-scale of curiosity of the professional adaptability, a statistically significant difference was also identified $(\mathrm{p}=0.001)$. The willingness of young adults to learn more about professional roles and possible situations of professional activity $(\mathrm{M}=4.31)$ is stronger compared to mature adults $(\mathrm{M}=3.23)$.

The comparison of the mean values of young and mature adults in the sub-scale of confidence revealed that difference between these groups is statistically significant $(\mathrm{p}=$ 0.001). The ability of mature adults to attain own professional goals and to overcome emerging obstacles is higher $(M=4.65)$ compared to young adults $(M=2.89)$.

The researchers have been in search for links of professional adaptability with different variables including age. Some of them have pointed out that such links do not exist, others have identified them in different age groups. Hirschi $(2009 ; 2010)$ carried out research on Swiss teenagers and pointed out that their professional adaptability is not related to age $(r=0.025 ; r=0.076)$. Ferreira (2012) conducted research on the professional adaptability of the respondents from four age groups (15-25, 26-40; 41-55 and 56-66 year old age groups) and revealed no correlation with age ( $\mathrm{p}>0.05)$.

Peeters \& Van Emmerik (2008) made an assumption that elder people face more difficulties adapting in their working places and, thus, their professional adaptability is weaker. The results of our research showed that the professional adaptability differs in groups of young and mature adults and this difference is statistically significant ( $\mathrm{p}=$ 0.001). The professional adaptivity of mature adults (35-41 year old individuals) is higher than that of young adults (21-25 year old individuals).

Takagi, Fuchigami \& Tanaka (2008), who conducted research on Japanese teachers, identified that the highest professional adaptability was observed among 40 year old respondents. The results of research by Harry and Coetzee (2013) revealed that the professional adaptability of the respondents positively correlated with age: the elder the 
respondents, the higher their professional adaptability. The results of our research confirmed the aforesaid conclusion.

Vilhjálmsdóttir and Dofradóttir (2012) carried out research on the professional adaptability of Icelanders in various age groups (in groups of 15-20 and 21-25 year old young adults and in groups of 36-45 and 46-65 year old mature adults). The researchers arrived at conclusions that the control and confidence are lower in groups of 15-20 and 21-25 year old young adults compared to groups of 36-45 and 46-65 year old mature adults. The 15-20 year old respondents compared to adults from 36-45 year old group demonstrated stronger curiosity and concern. The results of our research confirm all the aforesaid conclusions, with exception of the comparison of concern about their professional future between the groups of 15-20 year old respondents and 36-45 year old adults. This quality was expressed stronger by respondents of the former group.

O'Connell, McNeely \& Hall (2008) state that professional adaptability is related to the gender and educational background of the respondents. Coetzee \& Harry (2014) argue that groups of male and female respondents differed in their professional adaptability and hardiness. Shulman, Vasalampi, Barr, Livne, Nurmi \& Pratt (2014) have carried out the research on one hundred Israeli adults from 22 to 29 years old. The analysis of the research data revealed three variants of professional adaptability: integrated pattern of career adaptability, compromised pattern of career adaptability and vague pattern of career adaptability. The distinguishing of the aforesaid variants of professional adaptability may serve as basis for further research, which would aim to explain differences observed in groups of young and mature adults according to prevailing variants of professional adaptability. It is necessary to carry out further research in more varied samples and with a bigger number of respondents to test links of various factors of professional specialisation and professional adaptability.

\section{Conclusions}

1. The raised hypothesis that professional adaptability of young adults is lower compared to mature adults was confirmed. The differences in professional adaptability of young and mature adults are statistically significant $(\mathrm{p}=0.001)$.

2. The values of professional adaptability of young adults are bigger in the sub-scale of curiosity $(\mathrm{p}=0.001)$.

3. The values of professional adaptability of mature adults are bigger in the sub-scales of control $(p=0.001)$ and confidence $(p=0.001)$. 


\section{References}

Basova, V. (2012). The formation of social competence of graduates - the condition of the success of their professional socialization. International Journal of Academic Research, 4 (2), 179-181. Blustein, D. (2011). A relational theory of working. Journal of Vocational Behavior, 79, 1-17.

Bragg, A. (1976). The socialization process in higher education. Washington: George Washington University.

Clouder, L. (2003). Becoming professional: Exploring the complexities of professional socialization in health and social care. Learning in Health and Social Care, 2 (4), 213-222.

Coetzee, M., Harry, N. (2014). Emotional intelligence as a predictor of employees' career adaptivity. Journal of Vocational Behavior, 84 (1), 90-97.

Cohen, H. (1981). The nurse's quest for a professional identity. Menlo-Park: Addison-Wesley.

Creed, P., Fallon, T., Hood, M. (2009). The relationship between career adaptability, person and situation variables, and career concerns in young adults. Journal of Vocational Behavior, 74, 219-229.

Guzman, de A., Choi, K. (2013). The relation of employability skills to career adaptability among technical school students. Journal of Vocational Behavior, 82 (3), 199-207.

Del Corso, J. (2013). The theory of career adaptability. In A. Di Fabio, J. Maree (Eds.). Psychology of career counseling: New challenges for a new era (pp. 117-130). Exeter: Nova Science Publishers.

Del Corso, J., Rehfuss, M., Galvin, K. (2011). Striving to adapt: Addressing Adler's work task in the 21st century. Journal of Individual Psychology, 67, 88-106.

Fadjukoff, P., Kokko, K., Pulkkinen, L. (2010). Changing economic conditions and identity formation in adulthood. European Psychologist, 15, 293-303.

Ferreira, N. (2012). Constructing a psychological career profile for staff retention. Doctoral dissertation. University of South Africa.

Glawin, K., Berger, C. (2013). Assessing career adaptivity using the career Adaptabilities Scale. In A. Di Fabio, J. Maree (Eds.). Psychology of career counseling: New challenges for a new era (pp. 207-220). Exeter: Nova Science Publishers, Inc.

Hall, D., Zikic, J. (2010). Toward a more complex view of career exploration. Career Development Quarterly, 58 (2), 181-191.

Harry, N., Coetzee, M. (2013). Sense of coherence, career adaptability and burnout of early-career Black staff in the call centre environment. SA Journal of Industrial Psychology, 39 (2), 1-10.

Heckhausen, J., Wrosch, C., Schulz, R. (2010). A motivational theory of life-span development. Psychological Review, 117 (1), 32-60.

Heslin, P. (2005). Experiencing career success. Organizational Dynamics, 34 (4), 374-390.

Hirschi, A. (2009). Career adaptability development in adolescence: Multiple predictors and effect on sense of power and life satisfaction. Journal of Vocational Behavior, 74 (2), 145-155.

Hirschi, A. (2010). Swiss adolescents' career aspirations: Influence on context, age, and career adaptability. Journal of Career Development, 36 (3), 228-245. 
Jankauskienè, Ž. (2009). Professional socialization of nurses assuring practical activity. Doctoral dissertation. Vilnius: Vilnius University.

Keltikangas, K., Martinsuo, M. (2009). Professional socialization of electrical engineers in university education. European Journal Engineering Education, 34 (1), 87-95.

Melrose, S., Miller, J., Gordon, K., Janzen, K. (2012). Becoming socialized into a new professional role: LPN to BN student nurses' experiences with legitimation. Nursing Research and Practice, 1-8.

Nurmi, J.-E. (2004). Socialization and self-development: Channelling, selection, adjustment, and reflection. In R. Lerner, L. Steinberg (Eds.). Handbook of adolescent psychology (pp. 85-124). New York: John Wiley.

O’Connell, D., McNeely, E., Hall, D. (2008). Unpacking personal adaptability at work. Journal of Leadership and Organizational Studies, 14 (3), 248-259.

Peeters, M., Van Emmerik, I. (2008). An introduction to the work and well-being of older workers: From managing threats to creating opportunities. Journal of Managerial Psychology, 23 (4), 353-363.

Pulakos, E., Dorsey, D., White, S. (2006). Adaptability in the workplace: Selecting an adaptive workforce. In C. Burke, L. Pierce, E. Salas (Eds.). Understanding adaptability: A prerequisite for effective performance within complex environments (pp. 41-71). London: Elsevier Ltd.

Savickas, M. (1997). Career adaptability: An integrative construct for life-span, life-space theory. Career Development Quarterly, 45 (3), 247-259.

Savickas, M. (2005). The theory and practice of career construction. In S. Brown, R. Lent (Eds.). Career development and counseling: Putting theory and research to work (pp. 42-70). New York: Wiley.

Savickas, M. (2011). New questions for vocational psychology: premises, paradigms, and practices. Journal of Career Assessment, 19 (3), 251-258.

Savickas, M., Porfeli, E. (2011). Revision of the Career Maturity Inventory: The adaptability form. Journal of Career Assessment, 19 (4), 335-374.

Savickas, M., Porfeli, E. (2012). Career Adapt-Abilities Scale: Construction, reliability, and measurement equivalence across 13 countries. Journal of Vocational Behavior, 80, 661-673.

Schoen, S. (2007). Action research: A developmental model of Professional socialization. Journal of Educational Strategies, Issues and Ideas, 80 (5), 211-216.

Seada, A., Sleem, W. (2012). Professional socialization process and acquisition of professional nursing values among undergraduate nursing students. Journal of American Science, 8 (4), 678-688.

Shinyashiki, G., Mendes, I., Trevizan, M., Day, R. (2006). Professional socialization: students becoming nurses. Revista Latino-Americana de Enfermgem, 14 (4), 601-607.

Shulman, S., Vasalampi, K., Barr, T., Livne, Y., Nurmi, J.-E., Pratt, M. (2014). Typologies and precursors of career adaptability patterns among emerging adults: A seven-year longitudinal study. Journal of Adolescence, DOI: 10.1016/j.adolescence.2014.06.003 
Stark, J., Lowther, M., Hagerty, B., Orczyk, C. (1986). A conceptual framework for the study of pre-service professional programs in colleges and universities. Journal of Higher Education, 57 (3), 231-258.

Super, D. (1990). A life-span, life-space approach to career development. In D. Brown, L. Brooks (Eds.). Career choice and development (pp. 197-261). San Francisco: Jossey-Bass.

Takagi, R., Fuchigami, K., Tanaka, K. (2008). Causes of teachers' stress and career adaptability: A comparison across groups. Japanese Journal of Educational Psychology, 56 (2), 230-242.

Tolentino, L., Garcia, P., Lu, V., Bordia, P., Plewa, C. (2014). Career adaptation: The relation of adaptability to goal orientation, proactive personality, and career optimism. Journal of Vocational Behavior, 84 (1), 39-48.

Twale, D., Kochan, F. (1999). The teacup adventure: An educational leadership program in motion. International Studies in Educational Administration, 27 (1), 20-28.

Valutis, S., Rubin, D., Bell, M. (2012). Professional socialization and social work values: Who are we teaching? Social Work Education: The International Journal, 31 (8), 1046-1057.

Vilhjálmsdóttir, G., Dofradóttir, A. (2012). Social and developmental perspectives on career adaptability. IAEVG Conference Papers.

Waugaman, W., Lohrer, D. (2000). From nurse to nurse anesthetist: the influence of age and gender on professional socialization and career commitment of advanced practice nurses. Journal of Professional Nursing, 16 (1), 47-56.

Weidman, J., Twale, D., Stein, E. (2001). Socialization of graduate and professional students in higher education: A perilous passage? San Francisco: John Wiley and Sons, Inc.

Wrosch, C., Scheier, M., Miller, G., Schulz, R., Carver, C. (2003). Adaptive self-regulation of unattainable goals: goal disengagement, goal reengagement, and subjective well-being. Personality and Social Psychology Bulletin, 29 (12), 1494-1508.

\section{Profesinis jaunų suaugusiujų adaptyvumas: psichologinis profesinès socializacijos aspektas}

Julita Navaitienè

Lietuvos edukologijos universitetas, Edukacijos fakultetas, Psichologijos katedra,

Studentų g. 39, 8106 Vilnius, julita.navaitiene@leu.lt

\section{Santrauka}

Profesinè socializacija - procesas, kurio metu i̇gyjamos žinios, gebejjimai, interesai, vertybès ir vaidmenys, užtikrinantys asmens profesionalumą bei jo raidą. Profesinès socializacijos proceso efektyvumas gali būti analizuojamas profesinio adaptyvumo dimensijos 
aspektu, aiškinantis, kiek veiksmingai asmuo prisitaiko prie profesijos ir darbo rinkos reikalavimų, kad taptų profesinès bendruomenès nariu, sẻkmingai atliekančiu profesinị vaidmenị (Pulakos et al., 2006). Mokslininkai (Seada, Sleem, 2012) teigia, kad skirtingo amžiaus grupès statistiškai reikšmingai skiriasi pagal savo profesinę socializaciją. Kyla probleminis klausimas: jeigu profesinę socializaciją galima sieti su amžiumi, tai ar jaunų suaugusiųjų profesinis adaptyvumas yra mažesnis negu brandžių suaugusiųjų? Tyrimo tikslas buvo ištirti jaunų ir brandžių suaugusiųjų profesinį adaptyvumą. Tirti 44 Lietuvos edukologijos universiteto ištęstinių studijų studentai: 23 jauni suaugusieji (amžiaus vidurkis $M=23,1$ ) ir 21 brandus suaugusysis (amžiaus vidurkis $M=37,8$ ). Kelta hipotezé, kad jaunų suaugusiųjų profesinis adaptyvumas mažesnis negu brandžių suaugusiųjų, pasitvirtino. Profesinio adaptyvumo skirtumai tarp jaunų ir brandžių suaugusiųjų grupių statistiškai reikšmingi $(\mathrm{p}=0,001)$. Jaunų suaugusiųjų profesinio adaptyvumo ịverčiai didesni Smalsumo poskaleje ( $\mathrm{p}=0,001)$, o brandžių suaugusiųjų profesinio adaptyvumo ìverčiai didesni Kontrolès $(\mathrm{p}=0,001)$ ir Pasitikèjimo poskalèse $(\mathrm{p}=0,001)$.

Esminiai žodžiai: profesine socializacija, proaktyvi socializacija, profesinis adaptyvumas.

Iteikta / Received 2014-09-05

Priimta / Accepted 2014-10-12 